\title{
Responses of Growth and Mineral Nutrition of Garden Roses to Saline Water Irrigation
}

\author{
Genhua Niu ${ }^{1}$ \\ Texas AgriLife Research Center at El Paso, Texas A\&M University System, \\ 1380 A\&M Circle, El Paso, TX 79927
}

Terri Starman and David Byrne

Department of Horticultural Science, Texas A\&M University, 2133 TAMU, College Station, TX 77843

Additional index words. landscape irrigation, salt tolerance, water reuse, water-wise landscape

\begin{abstract}
The responses of garden roses to irrigation water with elevated salts are unknown. Two experiments were conducted to evaluate the relative salt tolerance of 13 self-rooted rose cultivars by irrigating the plants with nutrient solutions at an electrical conductivity (EC) of $1.4 \mathrm{dS} \cdot \mathrm{m}^{-1}$ (control) or nutrient saline solutions at EC of 3.1, 4.4, or $6.4 \mathrm{dS} \cdot \mathrm{m}^{-1}$. In Expt. 1, 'Belinda's Dream', 'Caldwell Pink', 'Carefree Beauty', 'Folksinger', 'Quietness', and 'Winter Sunset' plants were grown in a greenhouse from 13 Aug. to 21 Oct. (10 weeks). Shoot dry weight of all cultivars decreased as EC of irrigation water increased. 'Winter Sunset' was most sensitive among these cultivars to salt stress followed by 'Carefree Beauty' and 'Folksinger' with severe leaf injury at EC of $3.1 \mathrm{dS} \cdot \mathrm{m}^{-1}$ or higher or death at EC of 6.4 $\mathrm{dS} \cdot \mathrm{m}^{-1}$. No visual damage was observed in 'Belinda's Dream' or 'Caldwell Pink', regardless of the salinity level. In Expt. 2, 'Basye's Blueberry', 'Iceberg', 'Little Buckaroo', 'The Fairy', 'Marie Pavie', 'Rise N Shine', and 'Sea Foam' plants were grown in the greenhouse from 29 Sept. to 16 Nov. (7 weeks) and irrigated with the same nutrient or nutrient saline solutions. Salinity treatment did not affect shoot dry weight of 'Basye's Blueberry', 'Little Buckaroo', 'Sea Foam', and 'Rise N Shine'. Shoot dry weight of 'Iceberg', 'The Fairy', and 'Marie Pavie' decreased as EC of irrigation water increased. No or little visual damage was observed in 'Little Buckaroo', 'Sea Foam', and 'Rise N Shine'. Leaf tip burns were seen in 'Iceberg', 'Marie Pavie', 'Basye's Blueberry', and 'The Fairy' at EC $6.4 \mathrm{of} \mathrm{dS} \cdot \mathrm{m}^{-1}$. Generally, these symptoms were less severe than those observed in Expt. 1, probably attributable partially to the shorter treatment period. Whereas shoot $\mathrm{Na}^{+}$and $\mathrm{Cl}^{-}$varied greatly among the rose cultivars, the shoot concentrations of $\mathrm{Ca}^{2+}, \mathrm{K}^{+}$, and $\mathrm{Mg}^{2+}$ did not. Generally, salinity-tolerant cultivars had higher shoot $\mathrm{Na}^{+}$and $\mathrm{Cl}^{-}$concentrations. In summary, in Expt. 1, 'Belinda's Dream' was the most tolerant cultivar, whereas 'Winter Sunset' was the least tolerant followed by 'Carefree Beauty'. In Expt. 2, 'Iceberg', 'Marie Pavie', and 'The Fairy' were less tolerant to salinity as compared with other cultivars, although the differences were small.
\end{abstract}

In arid and semiarid regions, high-quality water supply is often limited and soil salinity is often high as a result of low rainfall and high evapotranspiration. With a rapid increase in urban populations, the intense competition for high-quality water among agriculture, industry, and recreational users has promoted the use of alternative water sources for irrigating landscapes in arid and semiarid regions. Alternative water, primarily municipal-treated effluents (also called reclaimed water), has higher salinity compared with that of potable water. In coastal regions, seawater intrusion

\footnotetext{
Received for publication 4 Feb. 2013. Accepted for publication 12 Mar. 2013

We gratefully acknowledge the financial support from Cooperative State Research, Education and Extension Service, U.S. Department of Agriculture under Agreement No. 2005-34461-15661, and Texas AgriLife Research.

${ }^{1}$ To whom reprint request should be addressed; e-mail gniu@ag.tamu.edu.
}

results in high soil salinity, whereas deicing salts also increase soil salinity in northern areas. Thus, tolerant plants are needed for these regions.

The relative salinity tolerance among multiple cultivars or species is often assessed based on survival rate, growth, and yield. Mineral analysis and other physiological responses to salinity help to understand the mechanisms of salinity tolerance (Carter and Grieve, 2006; Niu and Cabrera, 2010). Salinity reduces the ability of plants to take up water, and this quickly causes reductions in growth rate along with a suite of metabolic changes identical to those caused by water stress (Marschner, 1995; Munns, 2002). Increasing salinity stress as a result of higher salinity and/ or extended time exposure to salinity generally leads to foliar salt injury. For ornamental plants, being compact and free of foliar damage is more important compared with maximum growth. Many researchers have used visual ratings as one of the parameters to assess salinity tolerance (Cameron et al., 2004; Fox et al., 2005; Niu et al., 2008, 2012; Zollinger et al., 2007).

Sodium chloride is usually the primary salt in salinized soils and low-quality irrigation water. Ions of $\mathrm{Na}^{+}$and $\mathrm{Cl}^{-}$are often excessively absorbed by plants under salinity conditions, which reduce the uptake of other nutrients such as $\mathrm{Ca}^{2+}$ and $\mathrm{K}^{+}$. Most salttolerant plants have better ability to exclude $\mathrm{Na}^{+}$and/or $\mathrm{Cl}^{-}$to prevent their accumulation or limit the transport of these ions to shoots (Munns and Tester, 2008; Niu and Cabrera, 2010). Therefore, the shoot or leaf $\mathrm{Na}^{+}$and/or $\mathrm{Cl}^{-}$concentrations are often used to examine the salt tolerance of a plant and the mechanism of salt tolerance along with other parameters. For example, $R . \times$ fortuniana had higher $\mathrm{Na}^{+}$exclusion ability than $R$. multiflora and $R$. odorata, as evidenced by lower $\mathrm{Na}^{+}$ concentrations in stems and leaves (Niu et al., 2008).

Garden rose (Rosa spp.) is one of the most economically important and popular ornamental plants in the world. Rose has been traditionally categorized as a salt-sensitive species with salt injury reported within a range of 0.5 to $3 \mathrm{dS} \cdot \mathrm{m}^{-1} \mathrm{EC}$, depending on species and cultivar, cultural medium, leaching fraction, and environmental conditions (Urban, 2003). However, our previous research indicated that rose rootstocks $R$. fortuniana, $R$. multiflora, $R$. odorata, and 'Dr. Huey' could tolerate moderate salinity (EC up to $4.0 \mathrm{dS} \cdot \mathrm{m}^{-1}$ ) with acceptable growth reduction and aesthetic appearance (Niu et al., 2008; Niu and Rodriguez, 2008). Other researchers also reported that yield and quality of roses did not decrease when irrigated with drainage recycled water at $\mathrm{EC}$ of $3.5 \mathrm{dS} \cdot \mathrm{m}^{-1}$ provided that an appropriate rootstock and aerated medium were used (Cabrera, 2003; Raviv et al., 1998). More information on salt tolerance for greenhouse cut roses is available (Bernstein et al., 2006; Cabrera, 2003; de Vries, 2003; Fernández-Falcón et al., 1986; Hughes and Hanan, 1978; Wahome et al., 2001) as compared with garden roses, especially self-rooted roses. The objectives of this study were to compare the relative salt tolerance of selected garden roses, which are commonly used in southern regions, and to determine the mineral nutrition of these roses when irrigated with nutrient solution with increasing salinity.

\section{Materials and Methods}

Plant materials and cultural conditions. For Expt. 1, cuttings of 'Belinda's Dream', 'Caldwell Pink', 'Carefree Beauty', 'Folksinger', 'Quietness', and 'Winter Sunset' were taken on 7 Apr. 2010, dipped in 1000 ppm rooting hormone (Dip N Grow; EastWestHydro, Denver, CO) for $2 \mathrm{~s}$, stuck into $240-\mathrm{mL}$ pots filled with rooting medium Sunshine Mix. No. 1 (SunGro, Hort., Bellevue, WA), and placed on a mist bench. On 22 July, 2010, rooted plants were transplanted to 2.6-L plastic containers filled with Sunshine Mix No. 4 (SunGro). Plants were grown in the greenhouse and irrigated with nutrient solution 
before the initiation of treatment. Nutrient solution was prepared by adding $0.72 \mathrm{~g} \cdot \mathrm{L}^{-1}$ of $15 \mathrm{~N}-2.2 \mathrm{P}-12.5 \mathrm{~K}$ (Peters 15-5-15; Scotts, Marysville, $\mathrm{OH})$ to tap water and the EC of the solution was $1.4 \mathrm{dS} \cdot \mathrm{m}^{-1}$. The major ions in the tap water were $\mathrm{Na}^{+}, \mathrm{Ca}^{2+}, \mathrm{Mg}^{2+}, \mathrm{Cl}^{-}$, and $\mathrm{SO}_{4}{ }^{2-}$ at $184,52.0,7.5,223.6$, and 105.6 $\mathrm{mg} \cdot \mathrm{L}^{-1}$, respectively. Before treatments, uniform plants with the same number (two or three) of shoots, which varied with cultivar, were selected. All plants were pruned to the same height (two nodes per shoot).

For Expt. 2, cuttings of 'Basye's Blueberry', 'Iceberg', 'Little Buckaroo', 'The Fairy', 'Marie Pavie', 'Rise N Shine', and 'Sea Foam' plants were taken on 23 July 2010 using the same methodology as in Expt. 1. Rooted plants were transplanted on 9 Sept. to 2.6-L containers filled with the same substrate as described in Expt. 1 and irrigated with nutrient solution before initiating the treatment (29 Sept.). These cultivars were selected because they are commonly used in landscapes in southern regions of the United States.

Salinity treatment. For both experiments, four treatments were created: nutrient solution (control, no addition of salts, EC of 1.4 $\mathrm{dS} \cdot \mathrm{m}^{-1}$ ) and saline nutrient solutions at EC of $3.1,4.4$, or $6.4 \mathrm{dS} \cdot \mathrm{m}^{-1}$. Saline nutrient solutions at various salinity levels were prepared by adding calculated amounts of sodium chloride and calcium chloride at 2:1 (molar ratio) to the nutrient solution. Solutions were prepared in 100 -L tanks with confirmed EC and $\mathrm{pH}(\approx 6.5)$ each time. Plants were then irrigated (overwatering with a leaching fraction of $\approx 30 \%$ ) with nutrient or saline nutrient solutions whenever the substrate surface started to dry to prevent water stress. Irrigation intervals varied with plant size (biomass), treatment, and environmental conditions. To quantify the salt accumulation, leachate was collected every week and the EC of leachate was determined using an EC meter (Model B-173; Horiba, Ltd., Japan).

Expt. 1 started on 13 Aug. and ended on 21 Oct. 2010 (10 weeks), whereas Expt. 2 was from 29 Sept. to 16 Nov. 2010 ( 7 weeks). Plants in Expt. 1 were pruned on 2 Sept. (in the middle of the treatment duration) and the dry weight of pruned shoots was determined by oven-drying at $65^{\circ} \mathrm{C}$ to a constant weight. The average air temperature in the greenhouse for Expt. 1 was $27.4 \pm 1.4{ }^{\circ} \mathrm{C}$ and average daily integrated photosynthetically active radiation [daily light integral (DLI)] was $16.7 \pm 3.5 \mathrm{~mol} \cdot \mathrm{m}^{-2} \cdot \mathrm{d}^{-1}$. In Expt. 2, average air temperature was $24.3 \pm 2.4{ }^{\circ} \mathrm{C}$ and DLI was $15.8 \pm 3.8 \mathrm{~mol} \cdot \mathrm{m}^{-2} \cdot \mathrm{d}^{-1}$. A layer of shadecloth with $25 \%$ light exclusion was placed on top of the greenhouse roof from early April to early October, which reduced the differences in DLIs between the two experiments.

Measurement. At the end of each experiment, foliar salt damage was rated by giving a visual score based on a criterion reference scale from 0 to 5 , where $0=$ dead; $1=$ over $90 \%$ foliar damage (salt damage: burning, necrosis, and discoloration); $2=$ moderate $(50 \%$ to $90 \%)$ foliar damage; $3=$ slight (less than $50 \%$ ) foliar damage; $4=$ good quality with minimal foliar damage; and $5=$ excellent with no foliar damage. The foliar salt damage rating did not consider the plant size. For example, a score of 5 was given to a plant, if no salt damage was visible, although the plant was more compact as compared with the control.

Flowering characteristics were quantified by counting the number of flower buds, open flowers, and faded flowers. On termination, shoots were harvested and dry weight (DW) was determined after oven-drying at $65^{\circ} \mathrm{C}$ until a constant weight was reached. For Expt. 1, final shoot DW included the DW of pruned shoots, which was done during the treatment period.

Mineral analysis. To analyze shoot $\mathrm{Na}^{+}$ $\mathrm{Ca}^{2+}, \mathrm{Mg}^{2+}, \mathrm{K}^{+}$, and $\mathrm{Cl}^{-}$concentrations, four shoot samples were randomly collected. To minimize the number of samples, only the control and the highest salinity level (EC 6.4 $\mathrm{dS} \cdot \mathrm{m}^{-1}$ ) were sampled. Dried tissue samples were ground to pass a 40-mesh screen with a stainless Wiley mill (Thomas Scientific, Swedesboro, NJ) and the samples were submitted to the Soil, Water, and Air Testing Laboratory of New Mexico State University (Las Cruces, NM) for cation and anion analyses. Cation concentrations were determined by U.S. Environmental Protection Agency (EPA) method 200.7 (U.S. EPA, 1983) and analyzed using an Inductively Coupled Plasma/Atomic Emission Spectrophotometer Trace Analyzer (Thermo Jarrell Ash, Franklin, MA). $\mathrm{Cl}^{-}$was determined by EPA method 300.0 (U.S. EPA, 1983) and analyzed using an Ion Chromatograph (Dionex, Sunnyvale, CA).

Experimental design and statistical analysis. Both experiments followed a splitplot design with salinity of irrigation water as the main plot and cultivar subplots with 10 replications. All data were analyzed by a twoway analysis of variance using PROC GLM. When the main effect was significant, StudentNewman-Keuls multiple comparisons were performed to determine the differences among cultivars. Linear regression between salinity and shoot DW was conducted using PROC REG. All statistical analyses were performed using SAS software (Version 9.1.3; SAS Institute Inc., Cary, NC).

\section{Results}

Salinity effect on total number of flowers and buds varied with cultivar in both experiments (Table 1). In Expt. 1, the number of flowers and buds in 'Belinda's Dream' was unaffected by treatments. In all other cultivars, salt treatment significantly reduced the number of flowers and buds with highest reduction of $57 \%$ in 'Caldwell Pink', $76 \%$ in 'Carefree Beauty', $52 \%$ in 'Folksinger', $62 \%$ in 'Quietness', and $80 \%$ in 'Winter Sunset'. In Expt. 2, there were no salinity treatment differences in total number of flowers and buds in 'Rise-N-Shine' and 'Sea Foam'. In all other cultivars, the number of flowers and buds was reduced by salt treatment with the highest reduction of $77 \%$
Table 1. Total number of buds, open flowers, and faded flowers for 13 rose cultivars irrigated with nutrient solution (control, without addition of salts) or saline solution at electrical conductivity (EC) of $3.1,4.4$, or $6.4 \mathrm{dS} \cdot \mathrm{m}^{-1}$ (EC 3.1, EC 4.4, and EC 6.4) counted at the end of experiment.

\begin{tabular}{lrrrr}
\hline & \multicolumn{4}{c}{ Treatment } \\
\cline { 2 - 5 } Cultivar & Expt. 1 (10 weeks) & \\
\hline & & & \\
Belinda's Dream & $3.6 \mathrm{a}^{\mathrm{z}}$ & $3.5 \mathrm{a}$ & $3.3 \mathrm{a}$ & $2.7 \mathrm{a}$ \\
Caldwell Pink & $32.0 \mathrm{a}$ & $24.1 \mathrm{~b}$ & $19.1 \mathrm{bc}$ & $13.7 \mathrm{c}$ \\
Carefree Beauty & $6.3 \mathrm{a}$ & $3.5 \mathrm{~b}$ & $2.8 \mathrm{~b}$ & $1.5 \mathrm{~b}$ \\
Folksinger & $6.1 \mathrm{a}$ & $5.6 \mathrm{a}$ & $4.9 \mathrm{a}$ & $2.9 \mathrm{~b}$ \\
Quietness & $5.6 \mathrm{a}$ & $4.3 \mathrm{ab}$ & $2.3 \mathrm{~b}$ & $2.1 \mathrm{~b}$ \\
Winter Sunset & $6.7 \mathrm{a}$ & $4.5 \mathrm{~b}$ & $3.4 \mathrm{~b}$ & $1.4 \mathrm{c}$ \\
& & & & \\
& Expt. $2(7$ & weeks) & & \\
Basye's & $12.1 \mathrm{a}$ & $8.4 \mathrm{~b}$ & $3.6 \mathrm{c}$ & $2.8 \mathrm{c}$ \\
$\quad$ & & & & \\
Blueberry & $18.8 \mathrm{a}$ & $18.3 \mathrm{a}$ & $12.6 \mathrm{~b}$ & $9.8 \mathrm{~b}$ \\
Iceberg & $23.3 \mathrm{a}$ & $15.8 \mathrm{~b}$ & $8.5 \mathrm{c}$ & $7.4 \mathrm{c}$ \\
Little Buckaroo & $25.3 \mathrm{a}$ & $20.7 \mathrm{a}$ & $9.3 \mathrm{~b}$ & $6.7 \mathrm{~b}$ \\
Marie Pavie & $17.1 \mathrm{a}$ & $16.0 \mathrm{a}$ & $15.6 \mathrm{a}$ & $13.9 \mathrm{a}$ \\
Rise N Shine & $12.5 \mathrm{a}$ & $8.7 \mathrm{a}$ & $11.0 \mathrm{a}$ & $9.2 \mathrm{a}$ \\
Sea Foam & $75.1 \mathrm{a}$ & $65.8 \mathrm{a}$ & $60.4 \mathrm{a}$ & $35.3 \mathrm{~b}$ \\
The Fairy & &
\end{tabular}

${ }^{\mathrm{z}}$ Means in the same column with same letters are not significantly different among treatments tested by Student-Newman-Keuls multiple comparison at $P=0.05$. Analysis was conducted separately for both experiments.

in 'Basye's Blueberry', 48\% in 'Iceberg', $68 \%$ in 'Little Buckaroo', 74\% in 'Marie Pavie', and $53 \%$ in 'The Fairy'.

The highest leachate EC in Expt. 1 for the control, EC 3.1, EC 4.4, and EC 6.4 were 5.0, $6.8,8.3$, and $12.0 \mathrm{dS} \cdot \mathrm{m}^{-1}$, respectively. In Expt. 2, the highest leachate EC for the control, EC 3.1, EC 4.4, and EC 6.4 were 5.1, 7.6, 9.3, and $13.2 \mathrm{dS} \cdot \mathrm{m}^{-1}$, respectively. Salt accumulated in substrates in both experiments, which increased the salinity of the root zone (substrate). The higher the salinity of irrigation water, the more salt accumulated in the root zone, which is common in substrates containing peat (Niu and Rodriguez, 2006).

Visual rating. All plants in the control had a visual rating of 5.0, except for 'Folksinger' (Table 2). In Expt. 1, most plants survived the highest salinity treatment, except for 'Carefree Beauty' and 'Winter Sunset'. Thirty percent of the plants of these two cultivars did not survive the highest salinity (EC 6.4). 'Belinda's Dream' and Caldwell Pink' had similar best visual ratings, whereas 'Winter Sunset' had the lowest ratings among the six cultivars. At EC 6.4, 'Carefree Beauty' and 'Folksinger' also had very low ratings. 'Folksinger' plants were infected with powdery mildew in all treatments. 'Quietness' in EC 6.4 treatments had more severe salt damage, as compared with 'Belinda's Dream' and Caldwell Pink', with a rating of 4.4.

In Expt. 2, all plants survived with minor foliar damage in some cultivars. As a result of the shorter treatment period and relatively cool weather compared with those in Expt. 1, plants in Expt. 2 received milder salt stress. Among the seven, 'Iceberg', 'Marie Pavie', and 'The Fairy' had more obvious foliar salt damage in EC 4.4 and EC 6.4 treatments, 
which may indicate that these cultivars were less tolerant to salt stress. There were no differences in visual ratings between 'Basye's Blueberry' and 'Rise N Shine'. No or little visual damage was observed in 'Little Buckaroo' and 'Sea Foam'.

Shoot dry weight. Salinity and cultivar had significant interaction on shoot DW in both experiments. In Expt. 1, shoot DW decreased linearly as the salinity of irrigation water increased in all cultivars (Table 3 ). For 'Belinda's Dream', there were no differences

Table 2. Visual score of 13 rose cultivars irrigated with nutrient solution (control, without addition of salts) or saline solution at electrical conductivity (EC) of $3.1,4.4$, or $6.4 \mathrm{dS} \cdot \mathrm{m}^{-1}$ (EC 3.1, EC 4.4, and EC 6.4) assessed at the end of the experiments. ${ }^{\mathrm{z}}$

\begin{tabular}{lllll}
\hline & \multicolumn{4}{c}{ Treatment } \\
\cline { 2 - 5 } Cultivar & Control EC 3.1 & EC 4.4 & EC 6.4 \\
\hline Belinda's Dream & $5.0 \mathrm{a}^{\mathrm{y}}$. & $5.0 \mathrm{a}$ & $5.0 \mathrm{a}$ & $4.9 \mathrm{a}$ \\
Caldwell Pink & $5.0 \mathrm{a}$ & $5.0 \mathrm{a}$ & $5.0 \mathrm{a}$ & $4.9 \mathrm{a}$ \\
Carefree Beauty & $5.0 \mathrm{a}$ & $4.8 \mathrm{a}$ & $4.3 \mathrm{~b}$ & $1.5 \mathrm{c}$ \\
Folksinger & $4.0 \mathrm{a}$ & $4.2 \mathrm{a}$ & $4.8 \mathrm{a}$ & $2.2 \mathrm{~b}$ \\
Quietness & $5.0 \mathrm{a}$ & $5.0 \mathrm{a}$ & $5.0 \mathrm{a}$ & $4.4 \mathrm{~b}$ \\
Winter Sunset & $5.0 \mathrm{a}$ & $4.4 \mathrm{~b}$ & $2.5 \mathrm{c}$ & $1.2 \mathrm{c}$ \\
& & & & \\
Baspt. 2 & $5.0 \mathrm{a}$ & $5.0 \mathrm{a}$ & $4.9 \mathrm{ab}$ & $4.8 \mathrm{~b}$ \\
$\quad$ Blueberry & & & & \\
Iceberg & $5.0 \mathrm{a}$ & $5.0 \mathrm{a}$ & $4.8 \mathrm{~b}$ & $4.7 \mathrm{c}$ \\
Little Buckaroo & $5.0 \mathrm{a}$ & $5.0 \mathrm{a}$ & $5.0 \mathrm{a}$ & $5.0 \mathrm{a}$ \\
Marie Pavie & $5.0 \mathrm{a}$ & $5.0 \mathrm{a}$ & $4.9 \mathrm{ab}$ & $4.6 \mathrm{c}$ \\
Rise N Shine & $5.0 \mathrm{a}$ & $5.0 \mathrm{a}$ & $4.9 \mathrm{ab}$ & $4.8 \mathrm{~b}$ \\
Sea Foam & $5.0 \mathrm{a}$ & $5.0 \mathrm{a}$ & $5.0 \mathrm{a}$ & $4.9 \mathrm{a}$ \\
The Fairy & $5.0 \mathrm{a}$ & $5.0 \mathrm{a}$ & $4.9 \mathrm{ab}$ & $4.6 \mathrm{c}$ \\
\hline
\end{tabular}

${ }^{\mathrm{z}}$ Plants irrigated with nutrient solution had a visual score of 5.0, regardless of cultivar, except for 'Folksinger' that was infected with powdery mildew at the late part of the experiment and had a score of 4.0.

${ }^{y}$ Means in the same column with same letters are not significantly different among treatments tested by Student-Newman-Keuls multiple comparison at $P=0.05$. Analysis was conducted separately for both experiments.

Table 3. Shoot dry weight (DW, g/plant) of 13 rose cultivars irrigated with nutrient solution [control, without addition of salts, electrical conductivity (EC) 1.4] or saline nutrient solution at EC (EC) of 3.1, 4.4, or $6.4 \mathrm{dS} \cdot \mathrm{m}^{-1}$ (EC 3.1, EC 4.4, and EC 6.4).

\begin{tabular}{llllrl}
\hline & \multicolumn{4}{c}{ Treatment } & $\begin{array}{c}\text { Linear } \\
\text { Cultivar }\end{array}$ \\
\cline { 2 - 5 } & EC 1.4 & EC 3.1 & EC 4.4 & EC 6.4 & regsion $(P)$ \\
\hline Belinda's Dream & $21.0 \mathrm{a}^{\mathrm{z}}$ & $20.6 \mathrm{a}$ & $19.0 \mathrm{a}$ & $14.7 \mathrm{~b}$ & $0.003^{\mathrm{y}}$ \\
Caldwell Pink & $23.0 \mathrm{a}$ & $20.0 \mathrm{ab}$ & $18.3 \mathrm{~b}$ & $11.5 \mathrm{c}$ & $<0.0001$ \\
Carefree Beauty & $22.8 \mathrm{a}$ & $14.3 \mathrm{~b}$ & $11.8 \mathrm{~b}$ & $8.8 \mathrm{~b}$ & $<0.0001$ \\
Folksinger & $18.0 \mathrm{a}$ & $17.6 \mathrm{a}$ & $16.6 \mathrm{a}$ & $11.8 \mathrm{~b}$ & 0.0058 \\
Quietness & $29.5 \mathrm{a}$ & $22.7 \mathrm{~b}$ & $22.2 \mathrm{~b}$ & $16.3 \mathrm{c}$ & $<0.0001$ \\
Winter Sunset & $23.9 \mathrm{a}$ & $16.4 \mathrm{~b}$ & $14.2 \mathrm{~b}$ & $6.5 \mathrm{c}$ & $<0.0001$ \\
& & & & & \\
Basye's Blueberry & $11.9 \mathrm{a}$ & $11.4 \mathrm{a}$ & $10.1 \mathrm{a}$ & $8.8 \mathrm{a}$ & $\mathrm{NS}$ \\
Iceberg & $25.3 \mathrm{a}$ & $24.1 \mathrm{a}$ & $23.5 \mathrm{a}$ & $16.9 \mathrm{~b}$ & 0.0004 \\
Little Buckaroo & $20.8 \mathrm{a}$ & $19.5 \mathrm{a}$ & $17.9 \mathrm{a}$ & $16.1 \mathrm{a}$ & $\mathrm{NS}$ \\
Marie Pavie & $31.7 \mathrm{a}$ & $29.7 \mathrm{a}$ & $27.8 \mathrm{a}$ & $18.5 \mathrm{~b}$ & $<0.0001$ \\
Rise N Shine & $23.6 \mathrm{a}$ & $22.7 \mathrm{ab}$ & $19.3 \mathrm{~b}$ & $19.2 \mathrm{~b}$ & $\mathrm{NS}$ \\
Sea Foam & $12.5 \mathrm{a}$ & $10.2 \mathrm{a}$ & $11.2 \mathrm{a}$ & $11.6 \mathrm{a}$ & $\mathrm{NS}$ \\
The Fairy & $26.2 \mathrm{a}$ & $24.3 \mathrm{a}$ & $24.0 \mathrm{a}$ & $18.1 \mathrm{~b}$ & $<0.0001$ \\
\hline
\end{tabular}

${ }^{\mathrm{z}}$ Means in the same row with same letters are not significantly different among treatments tested by Student-Newman-Keuls multiple comparison at $P=0.05$. Analysis was conducted separately for both experiments.

${ }^{\mathrm{y}}$ Regression between shoot DW vs. salinity.

NS $=$ nonsignificant.

in shoot DW among the control, EC 3.1, and EC 4.4 treatments. Shoot DW at EC 6.4 was reduced by $30 \%$ compared with that of the control, whereas shoot DW at EC 4.4 was $70 \%$ that of the control. For 'Caldwell Pink', shoot DW at EC 4.4 was lower than that in the control and shoot DW at EC 6.4 decreased by $50 \%$ compared with the control. Shoot DW of Carefree Beauty' at EC 3.1 was significantly shoot DW of 'C $62 \%$ compared with control. For 'Folksinger', no differences were found in shoot DW among control, EC 3.1, and EC 4.4; however, shoot DW at EC 6.4 decreased by $35 \%$. For both 'Quietness' and 'Winter Sunset', shoot DW at EC 3.1 was lower than that of controls and decreased by $45 \%$ and $75 \%$ at EC 6.4 , respectively, compared with their respective controls.

In Expt. 2, salinity of irrigation water did not affect the shoot DW of 'Basye's Blueberry', 'Little Buckaroo', 'Rise N Shine', and 'Sea Foam' (Table 3). Shoot DW of 'Iceberg', 'Marie Pavie', and 'The Fairy' decreased linearly as salinity of irrigation water increased. The reduction percentages in these cultivars at EC 6.4 were $34 \%, 42 \%$, and $32 \%$ for 'Iceberg', 'Marie Pavie', and 'The Fairy', respectively, compared with their respective controls. The three cultivars with significant shoot DW reduction at EC 6.4 showed leaf margin burn, which resulted in lower visual ratings. The magnitude of shoot DW reduction was in agreement with severity of foliar salt damage (visual rating) in both experiments.

Mineral analysis (Expt. 1). Cultivar and treatment had an interactive effect on elements of $\mathrm{Na}^{+}, \mathrm{Cl}^{-}, \mathrm{Ca}^{2+}$, and $\mathrm{K}^{+}$, indicating that these mineral concentrations responded to salinity differently among cultivars (Fig. 1). For $\mathrm{Mg}^{2+}$, no significant differences were found among cultivars and there were no interactive differences between cultivar and treatment.
In the control, 'Carefree Beauty' and 'Folksinger' had the highest $\mathrm{Na}^{+}$concentrations in shoots followed by 'Winter Sunset', whereas 'Belinda's Dream', 'Caldwell Pink', and 'Quietness' had the lowest (Fig. 1). At EC 6.4, 'Folksinger' and 'Carefree Beauty' had the highest $\mathrm{Na}^{+}$concentrations, whereas the rest of the cultivars had statistically similar $\mathrm{Na}^{+}$concentrations.

For $\mathrm{Cl}^{-}$concentration in the control, 'Caldwell Pink' had a lower $\mathrm{Cl}^{-}$concentration compared with those of other cultivars. At EC 6.4, 'Folksinger' and 'Quietness' had higher $\mathrm{Cl}^{-}$concentrations compared with those of 'Belinda's Dream', 'Caldwell Pink', and 'Winter Sunset'. No differences were found in $\mathrm{Cl}^{-}$concentrations among 'Carefree Beauty', 'Folksinger', and 'Quietness' or among the other three cultivars.

For $\mathrm{Ca}^{2+}$ concentrations, in the control, 'Belinda's Dream' and 'Quietness' had the highest $\mathrm{Ca}^{2+}$ shoot concentration, whereas 'Folksinger' and 'Winter Sunset' had the lowest (Fig. 1). 'Caldwell Pink' and 'Carefree Beauty' had similar $\mathrm{Ca}^{2+}$ concentrations and were not different from those of 'Belinda's Dream' and 'Quietness'. At EC 6.4, 'Belinda's Dream' had the highest $\mathrm{Ca}^{2+}$ concentration followed by 'Quietness' and 'Caldwell Pink'. 'Carefree Beauty' had the lowest followed by 'Folksinger' and 'Winter Sunset'.

For $\mathrm{K}^{+}$concentration, in the control, 'Folksinger' had the highest followed by 'Caldwell Pink' and 'Winter Sunset', and by 'Belinda's Dream' and 'Quietness', and 'Carefree Beauty' had the lowest. At EC 6.4, 'Belinda's Dream' and 'Quietness' had the highest $\mathrm{K}^{+}$concentrations followed by 'Caldwell Pink', 'Folksinger' and 'Winter Sunset', and 'Carefree Beauty' had the lowest.

For $\mathrm{Mg}^{2+}$ concentration, because no differences were found among cultivars, data were pooled. The elevated salinity treatment increased shoot $\mathrm{Mg}^{2+}$ concentration by $20 \%$. The differences in $\mathrm{Ca}^{2+}, \mathrm{K}^{+}$, and $\mathrm{Mg}^{2+}$ among cultivars were smaller compared with those of $\mathrm{Na}^{+}$and $\mathrm{Cl}^{-}$regardless of salinity treatment.

Mineral analysis (Expt. 2). In Expt. 2, similar to Expt. 1, cultivar and treatment had an interactive effect on most elements of $\mathrm{Na}^{+}$, $\mathrm{Cl}^{-}$, and $\mathrm{Mg}^{2+}$, indicating that $\mathrm{Na}^{+}, \mathrm{Cl}^{-}$, and $\mathrm{Mg}^{2+}$ concentrations responded to salinity differently among cultivars (Fig. 2). For $\mathrm{Ca}^{2+}$ and $\mathrm{K}^{+}$, there were differences among cultivars but not among salinity treatments.

$\mathrm{Na}^{+}$concentrations in the control were highest in 'Sea Foam' followed by 'The Fairy', 'Iceberg', 'Marie Pavie', and 'Rise N Shine', whereas 'Basye's Blueberry' and 'Little Buckaroo' had the lowest. At EC 6.4, 'The Fairy' had the highest $\mathrm{Na}^{+}$concentration followed by 'Iceberg', 'Sea Foam', 'Little Buckaroo', 'Marie Pavie', and 'Basys's Blueberry' and 'Rise N Shine' had the lowest.

In the control, 'Marie Pavie' had the highest $\mathrm{Cl}^{-}$concentration followed by 'The Fairy', 'Iceberg', 'Sea Foam', and 'Rise N Shine', whereas 'Basye's Blueberry' and 'Little Buckaroo' had the lowest. At EC $6.4, \mathrm{Cl}^{-}$concentrations of 'Iceberg', 'Marie 

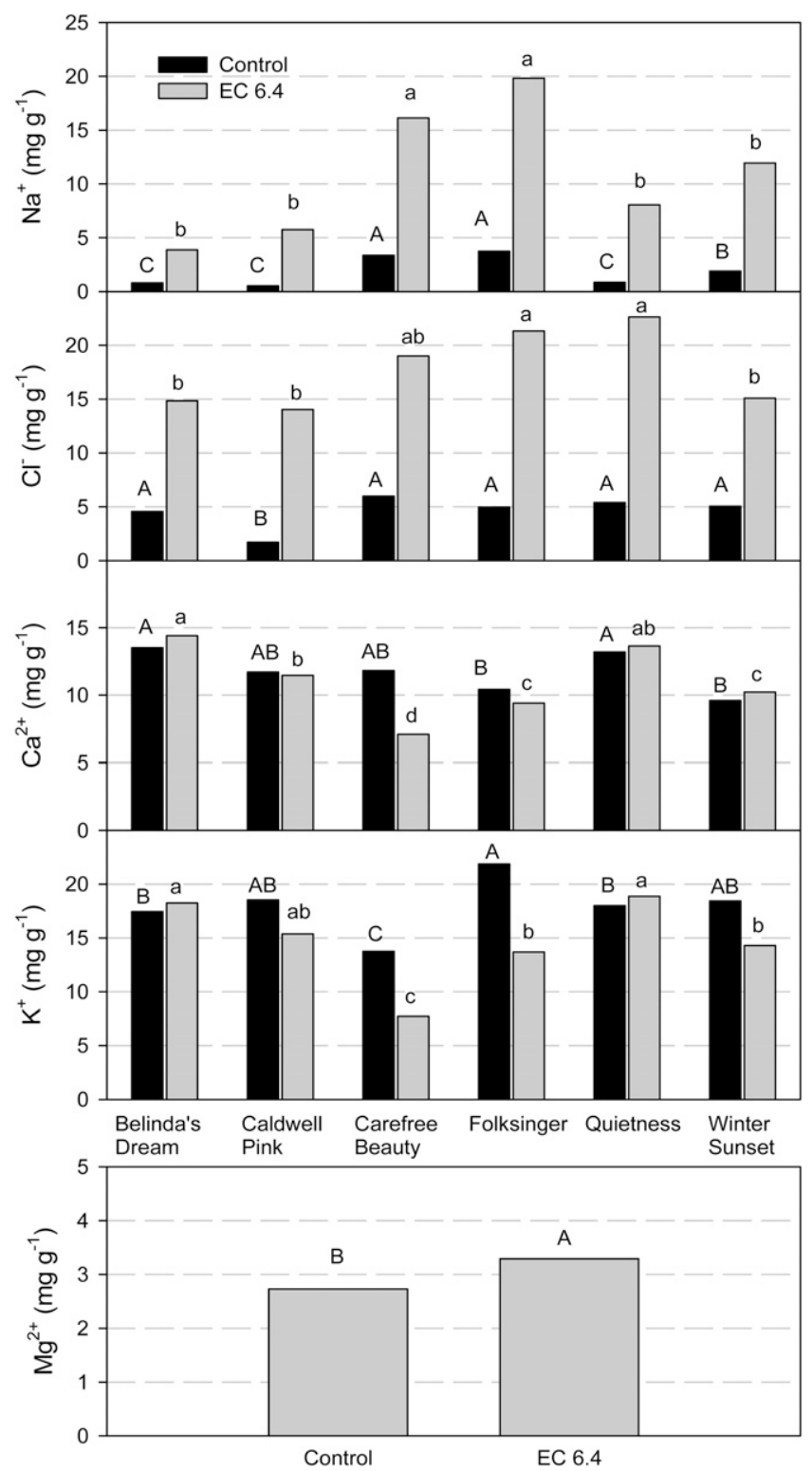

Fig. 1. Shoot sodium $\left(\mathrm{Na}^{+}\right)$, chloride $\left(\mathrm{Cl}^{-}\right)$, calcium $\left(\mathrm{Ca}^{2+}\right)$, potassium $\left(\mathrm{K}^{+}\right)$, and magnesium $\left(\mathrm{Mg}^{2+}\right)$ concentrations of six rose cultivars irrigated with nutrient solution (control, no addition of salts) or saline solution at electrical conductivity (EC) of $6.4 \mathrm{dS} \cdot \mathrm{m}^{-1}$ (EC 6.4) in Expt. 1. Mean with the same upper and lower case letters are not significantly different among cultivars in control and EC 6.4, respectively, tested by Student-Newman-Keuls multiple comparison at $P=0.05$.

Pavie', 'Rise N Shine', and 'The Fairy' were higher than those of 'Basye's Blueberry', 'Little Buckaroo', and 'Sea Foam'.

For $\mathrm{Ca}^{2+}$ concentration, there were no differences between salinity treatments and no interaction between cultivar and salinity treatment. Data were pooled for statistical analysis. 'The Fairy' had the highest $\mathrm{Ca}^{2+}$ concentration followed by 'Iceberg' and then by 'Marie Pavie', 'Rise N Shine', and 'Sea Foam'. 'Little Buckaroo' and 'Basys's Blueberry' had the lowest $\mathrm{Ca}^{2+}$ concentrations.

For $\mathrm{K}^{+}$concentration, there were no differences between salinity treatments and no interaction between cultivar and salinity treatment. Data were pooled for statistical analysis. 'Rise N Shine' had the highest $\mathrm{K}^{+}$concentration followed by 'Iceberg', 'Little Buckaroo', and 'Marie Pavie' and then by 'Sea Foam', whereas 'Basys's Blueberry' and 'The Fairy'

For $\mathrm{Mg}^{2+}$ concentration, in the control, 'The Fairy' had the highest, and 'Basye's Blueberry' and 'Little Buckaroo' had the lowest. There were no differences in $\mathrm{Mg}^{2+}$ concentrations between 'The Fairy' and 'Marie Pavie'; among 'Iceberg', 'Marie Pavie', and 'Rise N Shine'; and among 'Iceberg', 'Rise N Shine', and 'Sea Foam'. At EC 6.4, 'The Fairy' had the highest $\mathrm{Mg}^{2+}$ concentration, followed by 'Marie Pavie', and by 'Iceberg' and 'Rise N Shine'. The rest of the three cultivars had lower $\mathrm{Mg}^{2+}$ concentrations.

\section{Discussion}

Salt tolerance of crops is defined as the inherent ability of plants to withstand the had the lowest $\mathrm{K}^{+}$concentrations. effects of high salt concentrations in the root zone or on the leaves without a significant adverse effect such as foliar salt injury and growth and yield reduction (Grieve et al., 2008; Shannon et al., 1994). As salt stress becomes severe, leaves are generally negatively impacted, resulting in fewer green leaves. For ornamental plants, the typical symptoms of initial salt injury are stunted growth and foliar damage including leaf necrosis and marginal leaf burn (Bernstein et al., 1972; Grieve et al., 2008). Tolerance of salt stress for ornamental plants can be assessed based on survival rate, with or without foliar salt damage or the degree of foliar salt damage, and the degree of growth reduction (Niu and Cabrera, 2010). Aesthetic appearance is more important in ornamental plants than maximum growth and many researchers have used visual ratings to compare relative salt tolerance among tested species (Cameron et al., 2004; Fox et al., 2005; Niu et al., 2008, 2012; Zollinger et al., 2007).

In Expt. 1, 'Winter Sunset' and 'Carefree Beauty' were less tolerant to salinity as compared with the rest of the cultivars based on shoot growth and visual ratings. 'Belinda's Dream' was the most tolerant because it had highest visual quality and least shoot growth reduction. 'Caldwell Pink' was more tolerant to salinity as compared with 'Folksinger' and 'Quietness' because of its high visual quality, although shoot growth was reduced significantly. Using both the shoot growth and visual quality, based on the mentioned criterion for ornamental plants, 'Belinda's Dream' was the most tolerant followed by 'Caldwell Pink' and 'Quietness'. 'Winter Sunset' was the least tolerant followed by 'Carefree Beauty' and 'Folksinger'. For Expt. 2, 'Marie Pavie', 'The Fairy', and 'Iceberg' were less tolerant to salinity as compared with 'Basye's Blueberry', 'Sea Foam', 'Rise N Shine', and 'Little Buckaroo'. However, the differences among these seven cultivars were small.

According to Munns and Tester (2008), there are three distinct mechanisms of action for plants to adapt to salinity: osmotic stress tolerance, $\mathrm{Na}^{+}$or $\mathrm{Cl}^{-}$exclusion, and the tolerance of tissue to accumulated $\mathrm{Na}^{+}$or $\mathrm{Cl}^{-}$. In many cases, salt-tolerant genotypes have lower shoot $\mathrm{Na}^{+}$and/or $\mathrm{Cl}^{-}$concentrations because they have the ability to restrict $\mathrm{Na}^{+}$and/or $\mathrm{Cl}^{-}$ transport to shoots. However, some tolerant genotypes can tolerate high internal $\mathrm{Na}^{+}$or $\mathrm{Cl}^{-}$ concentrations such as Gazania rigen with $\mathrm{Na}^{+}$concentration of $39 \mathrm{mg} \cdot \mathrm{g}^{-1} \mathrm{DW}$ in shoots (Niu and Rodriguez, 2006). Ion uptake depends on species or genotype, salinity level, treatment period, and the chemical composition of the salinity (Grattan and Grieve, 1999; Niu and Rodriguez, 2008).

In this study, differences in shoot $\mathrm{Na}^{+}$and $\mathrm{Cl}^{-}$concentrations were significant among cultivars, even in the control, in both experiments. 'Carefree Beauty' and 'Folksinger' had higher $\mathrm{Na}^{+}$concentrations compared with other cultivars. Although $\mathrm{Na}^{+}$and $\mathrm{Cl}^{-}$ of 'Winter Sunset' were not the highest, its tolerance to salt stress was the least, indicating that this cultivar had lower damage 


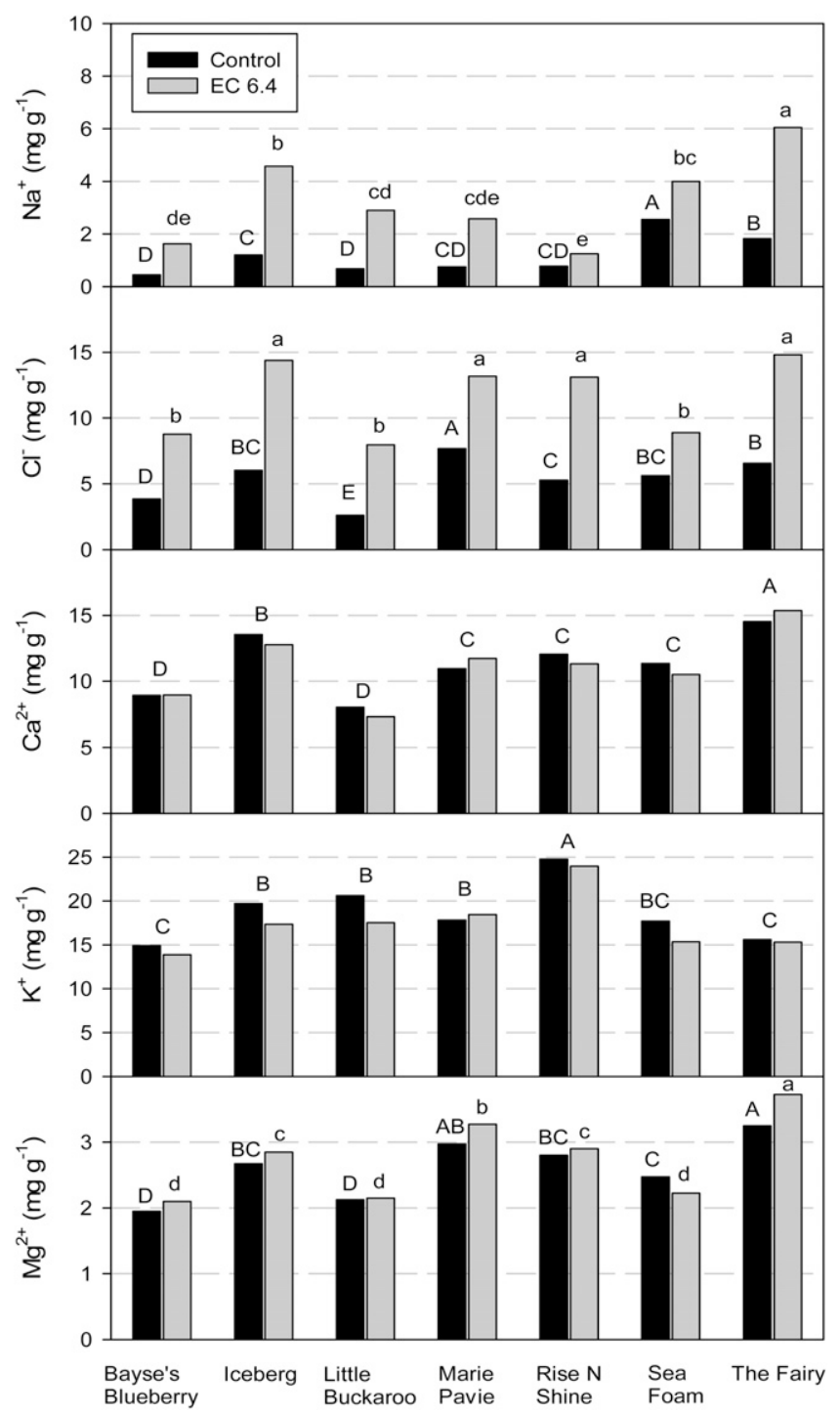

Fig. 2. Shoot sodium $\left(\mathrm{Na}^{+}\right)$, chloride $\left(\mathrm{Cl}^{-}\right)$, calcium $\left(\mathrm{Ca}^{2+}\right)$, potassium $\left(\mathrm{K}^{+}\right)$, and magnesium $\left(\mathrm{Mg}^{2+}\right)$ concentrations of seven rose cultivars irrigated with nutrient solution (control, no addition of salts) or saline solution at electrical condutivity (EC) of $6.4 \mathrm{dS} \cdot \mathrm{m}^{-1}$ (EC 6.4) in Expt. 2. Mean with the same upper and lower case letters are not significantly different among cultivars in the control and EC 6.4, respectively, tested by Student-Newman-Keuls multiple comparison at $P=0.05$. For $\mathrm{Ca}^{2+}$ and $\mathrm{K}^{+}$, no differences were found between control and salt treatment. Therefore, data for multiple comparisons were pooled.

threshold for $\mathrm{Na}^{+}$and $\mathrm{Cl}^{-}$concentrations. In Expt. 2, 'The Fairy' had higher $\mathrm{Na}^{+}$concentration and relatively obvious foliar damage compared with other cultivars. For all cultivars in both experiments, shoot $\mathrm{Na}^{+}$concentrations were lower than $\mathrm{Cl}^{-}$concentrations, but both $\mathrm{Na}^{+}$and $\mathrm{Cl}^{-}$concentrations varied with cultivar. $\mathrm{Na}^{+}$concentrations for most cultivars in this study were rather high compared with rose rootstocks of $R$. fortuniana $\left(1.1 \mathrm{mg} \cdot \mathrm{g}^{-1}\right)$, $R$. multiflora (2.2 $\left.\mathrm{mg} \cdot \mathrm{g}^{-1}\right), R$. odorata $(3.1$ $\left.\mathrm{mg} \cdot \mathrm{g}^{-1}\right)$, and 'Dr. Huey' $\left(1.3 \mathrm{mg} \cdot \mathrm{g}^{-1}\right)(\mathrm{Niu}$ et al., 2008), although the treatment period was shorter and salinity level was lower than those for the rose rootstocks (16 weeks, EC of $8.0 \mathrm{dS} \cdot \mathrm{m}^{-1}$ ).

Excessive accumulation of $\mathrm{Na}^{+}$often results in a low $\mathrm{K}^{+}$concentration (Grattan and Grieve, 1999). Maintaining adequate $\mathrm{K}^{+}$concentrations is essential to survive and thrive under salinity stress. $\mathrm{Ca}^{2+}$ uptake is often disturbed under saline conditions (Alam et al., 2001). Even under non-saline conditions, inadequate calcium nutrition occurs in many horticultural crops as a result of physical or chemical stresses (Grattan and Grieve, 1999). In Expt. 1, the salt-sensitive cultivars Carefree Beauty, Winter Sunset, and Folksinger had lower $\mathrm{K}^{+}$and $\mathrm{Ca}^{2+}$ concentrations under elevated salinity conditions. These results are supported by other authors (Drihem and Pilbean, 2002; Marosz, 2004; Rodriguez-Perez et al., 2000). The reduction in $\mathrm{Ca}^{2+}, \mathrm{K}^{+}$, and $\mathrm{Mg}^{2+}$ by elevated salinity in Expt. 2 was not substantial as compared with those in Expt. 1.

In summary, salt tolerance of the selfrooted garden roses varied with cultivar. In Expt. 1, 'Belinda's Dream' was the most tolerant, 'Caldwell Pink' and 'Quietness' also had good tolerance to salinity, whereas 'Winter Sunset', 'Carefree Beauty', and
'Folksinger' were the least tolerant. In Expt. 2, 'Marie Pavie', 'The Fairy', and 'Iceberg' were less tolerant to salinity as compared with 'Basye's Blueberry', 'Sea Foam', 'Rise N Shine', and 'Little Buckaroo'. Because the differences among cultivars in visual quality and shoot growth were small in Expt. 2, further study is needed to confirm the results. Large variations in shoot $\mathrm{Na}^{+}$and $\mathrm{Cl}^{-}$concentrations existed among cultivars under both control and elevated salinity treatments.

\section{Literature Cited}

Alam, S., S.M. Imamul Hug, S. Kawai, and A. Islam. 2001. Effects of applying calcium salts to coastal saline soils on growth and mineral nutrition of rice varieties. J. Plant Nutr. 3:561567.

Bernstein, L., L.E. Francois, and R.A. Clark. 1972. Salt tolerance of ornamental shrubs and ground covers. J. Amer. Soc. Hort. Sci. 97:550-556.

Bernstein, N., B.T. Asher, F. Haya, S. Pini, R. Ilona, C. Amram, and I. Marina. 2006. Application of treated wastewater for cultivation of roses (Rosa hybrida) in soil-less culture. Sci. Hort. 108:185-193.

Cabrera, R.I. 2003. Demarcating salinity tolerance in greenhouse roses. Acta Hort. 609:51-57.

Cameron, R.W.F., S. Wilkinson, W.J. Davies, R.S. Harrison-Murray, D. Dunstan, and C. Burgess. 2004. Regulation of plant growth in containergrown ornamentals through the use of controlled irrigation. Acta Hort. 630:305-312.

Carter, C.T. and C.M. Grieve. 2006. Salt tolerance of floriculture crops, p. 279-287. In: Khan, M.A. and D.J. Weber (eds.). Ecophysiology of high salinity tolerant plants. Springer, The Netherlands.

de Vries, D.P. 2003. Rootstock, p. 633-638. In: Robert, A. V. T. Debener, and S. Gudin (eds.). Encyclopedia of rose science. Elsevier Academic Press, San Diego, CA.

Drihem, K. and D.J. Pilbean. 2002. Effect of salinity on accumulation of mineral nutrients in wheat grown with nitrate-nitrogen or mixed ammonium: Nitrate-nitrogen. J. Plant Nutr. 10:2091-2113.

Fernández-Falcón, M., C.E. Álvarez, V. Garcia, and J. Baez. 1986. The effect of chloride and bicarbonate levels in irrigation water on nutrient content, production and quality of cut roses 'Mercedes'. Sci. Hort. 29:373-385.

Fox, L.J., J.N. Grose, B.L. Appleton, and S.J. Donohue. 2005. Evaluation of treated effluent as an irrigation source for landscape plants. J. Env. Hort. 23:174-178.

Grattan, S.R. and C.M. Grieve. 1999. Salinitymineral nutrient relations in horticultural crops. Sci. Hort. 78:127-157.

Grieve, C., L. Wu, L. Rollins, and A. Harivandi. 2008. Tolerance by landscape plants of salinity and of specific ions. In: A comprehensive literature review on salt management guide for landscape irrigation with recycled water in coastal southern California. 1 Feb. 2013. $<\mathrm{http}$ /www.salinitymanagement.org $>$.

Hughes, H. and J. Hanan. 1978. Effect of salinity in water supplies on greenhouse rose production. J. Amer. Soc. Hort. Sci. 103:694-699.

Marosz, A. 2004. Effect of soil salinity on nutrient uptake, growth, and decorative value of four ground cover shrubs. J. Plant Nutr. 27:979989.

Marschner, H. 1995. Mineral nutrition of higher plants. 2nd Ed. Academic Press, San Diego, CA. 
Munns, R. 2002. Comparative physiology of salt and water stress. Plant Cell Environ. 25:239-250.

Munns, R. and M. Tester. 2008. Mechanisms of salinity tolerance. Annu. Rev. Plant Biol. 59:651-681.

Niu, G. and R . Cabrera. 2010. Growth and physiological responses to landscape plants to saline water irrigation-A review. HortScience 45: $1605-1609$.

Niu, G. and D.S. Rodriguez. 2006. Relative salt tolerance of selected herbaceous perennials and groundcovers. Sci. Hort. 110:352-358.

Niu, G. and D.S. Rodriguez. 2008. Responses of growth and ion uptake of four rose rootstocks to chloride- or sulfate-dominated salinity. J. Amer. Soc. Hort. Sci. 133:663-669.

Niu, G., D.S. Rodriguez, and L. Aguiniga. 2008. Effect of saline water irrigation on growth and physiological responses of three rose rootstocks. HortScience 43:1479-1484.

Niu, G., D. Rodriguez, and S. McKenney. 2012. Response of selected wildflower species to saline water irrigation. HortScience 47:1351-1355.

Raviv, M., A. Krasnovsky, S. Medina, and R. Reuveni. 1998. Assessment of various control strategies for recirculation of greenhouse effluents under semi-arid conditions. J. Hort. Sci. Biotechnol. 73:485-491.

Rodriguez-Perez, J.A., M. Fernandez-Falcon, and A.R. Socorro-Monzon. 2000. The effect of salinity on growth and nutrition of Protea obtusifolia. J. Plant Nutr. 1:97-104.

Shannon, M.C., C.M. Grieve, and L.E. Francois. 1994 Whole-plant response to salinity, p. 199-244. In: Wilkinson, R.E. (ed.). Plant environment interaction. Marcel Dekker, New York, NY.
Urban, I. 2003. Influences of abiotic factors in growth and development, p. 369-374. In: Robert, A.V., T. Debener, and S. Gudin (eds.). Encyclopedia of rose science. Elsevier Academic Press, San Diego, CA.

U.S. Environmental Protection Agency. 1983 Methods of chemical analysis of water and wastes (EPA-600/4-79-020). U.S. Gov. Print. Office, Washington, DC.

Wahome, P.K., H.H. Jesch, and I. Grittner. 2001 Mechanisms of salt stress tolerance in two rose rootstocks: Rosa chinensis 'Major' and $R$. rubiginosa. Sci. Hort. 87:207-216.

Zollinger, N., R. Koenig, T. Cerny-Koenig, and R. Kjelgren. 2007. Relative salinity tolerance of intermountain western United States native herbaceous perennials. HortScience 42:529534. 